\title{
Cultural Diversity in the Use of Action Verbs in Indonesian Senior High School English e-Textbooks: A Qualitative Content Analysis
}

\author{
Jennifer \\ Sanata Dharma University, Indonesia. \\ Email: keisdhi.jennifer@gmail.com \\ Ouda Teda Ena \\ Sanata Dharma University, Indonesia \\ Email: ouda@usd.ac.id
}

\begin{abstract}
Having a purpose of providing all Indonesian students with cheap but qualified textbooks, the e-textbooks should be culturally inclusive, which are able to make the students engage with the texts, and later be motivated to learn. Ena (2013) and Wulandari (2019) found cultural biases in English e-textbooks for senior high schools in Indonesia, which could demotivate students from certain cultural groups, which were underrepresented or represented unfairly. Thus, aiming to elaborate to what extent diversity is represented in the action verbs of the e-textbooks studied, qualitative content analysis was chosen for this study. The reseachers were the main instruments, followed by categorizations and interraters. The results showed there was ethnicity bias. There was no Melanesian animal subjects using action verbs at all in all the e-textbooks and Melanesian human subjects never dominated any e-textbook, while Foreign subjects, who in reality are less in number than the Melanesian, dominated the etextbook for grade X. Since there was ethnicity bias in the e-textbooks, all the parties involved in the creation of the e-textbooks should either vary the writer team's ethnicities or vary the texts' cultural settings and make them in line with the population rank of ethnicities in Indonesia.
\end{abstract}

Keywords: linguistic category model, qualitative content analysis, gender, ethnicity, e-textbook

\section{INTRODUCTION}

In terms of diversity, Indonesia is proven to be diverse in ethnicities and gender roles. Parker $\&$ Hoon (2013) and Mavridis (2015) conclude that there are more than 300 ethnic groups and 700 living languages in Indonesia. Meanwhile, Ananta et al. (2015) in Arifin et al. (2015) re-classify more than 600 ethnic groups from the raw data of 2010 population census. It proves that Indonesia is one of the most diverse in terms of ethnicity. There is a gap between men and women who do not have school certificates, i.e. men $14.34 \%$ and women $19.66 \%$. (Hakiki \& Ulfa, 2018, p. 22) In rural areas, the number of women who do not have school certificates is $6,37 \%$ higher than that of men. (Hakiki \& Ulfa, 2018, p. 22) Ena (2013) further explains that women are often discouraged when it comes to education.

Considering the great diversity in Indonesia, all parties concerning in Indonesian education are challenged to provide culturally relevant learning materials which affect students' intellectuality, social lives, emotion, and political perspectives. (Ena, 2013, p. 34) Materials are culturally relevant if they represent learners wisely. In Ena's (2013) research, biases are found in English e-textbooks for senior high schools in Indonesia. The e-textbooks do not represent the two cultural aspects of Indonesian learners wisely.

Nevertheles, according to National Education Minister's Regulation number 2 in 2008, textbooks are mandatory references for elementary school, junior high school, senior high school, and higher education "in order to develop faith, piety, noble characters, and personality; mastery of science, knowledge and technology; and to develop sensitivity, aesthetic abilities, kinesthetic and health abilities which are compiled based on national education standards" As textbooks are mandatory for schools in all provinces of Indonesia which are culturally diverse; the textbooks, especially 2013 curriculum textbooks which are issued by the government, must include as many cultural aspects as they can and represent all the cultural aspects wisely because cultural representations in textbooks affect students' motivation to learn (Ena, 2013). This study attempts to exami- 
ne whether 2013 curriculum English textbooks for senior high school represent all the cultural aspects wisely.

Only few researchers studied Indonesian textbooks and e-textbooks even though according to National Education Minister's Regulation number 2 in 2008, textbooks are the main source of learning. Ena's (2013) study on how diversity was signified in the visual images showed that the cultural representations in the English e-textbooks, which were published in 2008 and followed 2006 curriculum, were inequal. The etextbooks, appointed to Indonesian senior high school students, also enclosed gender roles stereotypes. Because of the inequality, Ena (2013) argues that students whose cultural backgrounds are marginalized tend to lose their motivation to study. Ena's (2013) study needs to be replicated due to the change of curriculum and studies on representations of diversity in e-textbooks need to be extended. Ena's (2013) study elaborated only visual images. Linguistic aspects in e-textbooks were not elaborated yet.

In Candrawati, Nitiasih, and Seken's (2014) study, linguistic aspects and sociocultural aspects were elaborated. The e-textbook studied was an English e-textbook for students of grade twelve in senior high school. The e-textbook was published in 2009. The e-textbook follows 2006 curriculum. Candrawati et al. (2014) found that the age group appearing in the e-textbook was appropriate for the students using the e-textbook. However, the e-textbook was male-oriented, and it contained a few sexist words. It can be concluded that the e-textbook still contains inequal representations.

Candrawati et al. (2014) conducted a research deeply on one e-textbook. This study elaborated two aspects of cultural diversity in all the e-textbooks for senior high school students. All the e-textbooks were the e-textbooks of 2013 curriculum (the newest curriculum) which were published in 2017 (the newest edition) for senior high school. In Candrawati's et al. (2014) study, linguistic aspects elaborated as means of representations were mostly subjects. For example, when expounding gender, Candrawati et al. (2014) paid greater attention to the number of male and female subjects. Another research on subjects in e-textbooks is Wulandari's (2019). Wulandari (2019) uses Miller's (2001 in Wulandari, 2019) theory of subjects, which are defined as "the Agent in the situation described" (Miller, 2001, p. 88 in Wulandari, 2019, p. 18), which is elaborated more by Jackson (2013) that a subject can be agentive or non-agentive, but Wulandari's (2019) limited her study to subjects in general.

Having the same concern with the previous studies, after Candrawati et al. (2014) and Wulandari (2019) studied the subjects in the e-textbooks, there was a need to study other semantic roles, so the study of action verbs was chosen. Action verb is a verb which is executed by an actor usually due to a will e.g. kick, start, drink, eat, help, discover, talk, read. (Greifeneder, Bless, and Fiedler, 2018, p. 178; Jackson, 2013; Kratzer, 1996; Olsen, 2014) This study is the elaboration of agents and its effects on diversity representation and linguistic intergroup bias, which can relate to Candrawati's et al. (2014) and Wulandari's (2019) studies, due to Jackson's (2013) theory that a subject (the previous studies mentioned are about subjects) can be agentive or non-agentive.

Up to 2009 (Candrawati et al., 2014), textbooks and e-textbooks are still not aware of sociocultural aspects. According to Celce-Murcia (2007, p. 46), foreign and second language teachers tend to be far more aware of grammar than sociocultural behaviors. Not many teachers teach their students to be aware of social and cultural context when communicating. (Celce-Murcia, 2007; Amri, Bin-Tahir, and Ahmad, 2017) Indonesian students, who live in a multicultural country, should be taught values of multicultural education, e. g. human values, inclusive values, and equality values. (Tilaar, 2009) Teaching values of multicultural education will not succeed if the e-textbooks used for learning contain marginalization of certain sociocultural backgrounds and cultural stereotypes.

Regarding this fact, this study aims to elaborate to what extent ethnic diversity and gender role diversity are represented in the action verbs of the English e-textbooks of 2013 curicculum (the newest e-textbooks of the newest curriculum) for high school in Indonesia. This study is vital to raise society's awareness of applying values of multicultural education in textbooks, including e-textbooks, and of the current multicultural qualities the newest e-textbooks possess. Society is expected to keep comparing the ideal representations of cultural diversity, a part of multicultural qualities, with the actual representations of cultural diversity in the current e-textbooks issued by the government.

\section{METHODOLOGY}

The subjects of this study are: (1) Bahasa Inggris SMA/MA/SMK/MAK kelas X (Revised edition, published in 2017); (2) Bahasa Inggris SMA/MA/SMK/MAK kelas XI (Revised 
edition, published in 2017); (3) Bahasa Inggris SMA/MA/SMK/MAK kelas XII (Revised edition, published in 2018). They are in a form of authentic and complete documents. They can be accessed by schools or institutions on bse.kemdikbud.go.id/

Qualitative content analysis, chosen as the methodology of this study, was what synthesizes theories of diversity and action verbs. The framework of qualitative content analysis used in this study was mainly the framework which the writers got from Drisko and Maschi (2016). Qualitative content analysis is defined as an interpretive research methodology whose purpose is to analyze contents by using systematic, valid, replicable, and transparent techniques. (Bengtsson, 2016, p. 9; Cho \& Lee, 2014, p. 1; Drisko \& Maschi, 2016, p. 7; Elo et al., 2014, p. 18; Krippendorff, 2004, p. 18; Moretti et al., 2011, p. 420) Drisko and Maschi (2016) collect and condense theories of qualitative content analysis and point out the essential rigors which make qualitative analysis different from quantitative analysis, which are replicability instead of reliability and transparency instead of objectivity. The thing on the surface that makes the difference between qualitative content analysis and quantitative analysis clearly visible is that a writer's personal consideration regarding categorizations and inference from the categorized data is taken into account, highlighting the value of intersubjectivity as a way of describing social phenomena. (Drisko \& Maschi, 2016; Krippendorff, 2004; Neuendorf, 2002)

The ethnic and gender role diversity was converted into cultural categorizations as one of research instruments in this study. The writers' personal considerations were needed to identify the clause subjects' cultural backgrounds (ethnicity and gender role) in the e-textbooks and afterwards to categorize them into cultural categorizations.

After having qualitative content analysis and diversity frameworks, the action verb framework enriched the study well because the action verb framework was a part of Linguistic Category Model, which was often used to elaborate intergroup discrimination phenomena. (Rubini et al., 2007; Semin, 2008) Action verb is a verb which is executed by an actor usually due to a will e.g. kick, start, drink, eat, help, discover, talk, read. (Greifeneder et al., 2018, p. 178; Jackson, 2013; Kratzer, 1996; Olsen, 2014) In this study, firstly, action verb had three categories, namely positive e.g. help, negative e.g. hurt, and neutral e.g. eat. After the data collection, the categories were changed into 1) positive to neutral action verbs and 2) negative action verbs. This study's purpose was mainly to elaborate how many positive to neutral and negative action verbs were used for clause subjects who belong to various ethnicities and gender roles. The categorization or coding processes were also elaborated in order to validate the instruments and the results.

The first instrument is the researchers and the second instrument is the categorizations. The second researcher (Ouda Teda Ena) sorted all the verbs in the e-textbooks into action verbs. The first researcher coded the action verbs into positive, neutral, or negative; and at the same time classified the subjects of that of action verbs into the gender role categories (male, female, unidentified) and the ethnicity categories (Austronesian, Melanesian, Foreign). Multiple coding was done by the first researcher in order to maintain consistency. The first coding was coded J1 and the second coding (taken a month afterward) was coded J2.

The third instrument is interraters. A rater is somebody who rates data based on categories. Interraters were needed to counter the potential bias of the first researcher's categorization and interpretation.

What can be replicated from interraters as an instrument is the process of how interrater reliability or interrater agreement is achieved. Once it is achieved, the use of interraters as an instrument can be deemed to be valid.

Four interraters were employed in this study. The first two interraters were employed to sort action verbs from 800 sentences $(11.11 \%$ of the total sentences containing verbs as a word class in all the e-textbooks studied, considering Ari, Jacobs \& Sorensen's (2010) argument that at least the random $7 \%$ of the total linier data should represent the whole data). The first two interraters' initials are IK and AW. Afterward, the second two interraters were employed to sort the subjects of the action verbs into cultural categories made by the researchers but new categories could be added along the process of coding. The second two interraters were given 8 chapters of the e-textbook for grade X (first grade), which contained $23.53 \%$ of the total sentences containing action verbs in all the e-textbooks studied. The second two raters have different backgrounds from each other and from the first researcher. They have different gender and different ethnicities from the first researcher. The first researcher's gender and ethnicity are female and Javanese respectively. Both cultural interraters are males. One of them is Indonesian-Chinese (whose initial is EHS) and the other is Alorese (whose initial is $\mathrm{KN}$ ). 
Due to the need of multiple raters whose cultural backgrounds differ from the first writer's, the rating or coding process done by multiple raters has to reach agreement. Therefore, interrater agreement is needed in this study. Shrout and Fleis $(1979$, p. 420) also point out that human judgements often encounter errors which can seriously affect analyses and interpretations. Thus, it is important to assess interrater agreement. Interrater agreement is assessed by using percent agreement by Holdford (2008); Gisev et al. (2013). Percent agreement is used in (1) Baveye, Dellandréa, Chamaret, and Chen (2015); (2) Cavazos-Rehg, Krauss, Sowles, Connolly, Rosas, Bharadwaj, and Bierut (2016); (3) Jenkins, Yang, Ramalingam, Yu, Patel, Weston, Hodge, Cantarini, Jänne, Mitsudomi, and Goss (2017); (4) Tixier, Hallowell, Rajagopalan, and Bowman (2016). Agreement between each rater and the first researcher was tested by using percent agreement (Holdford, 2008; Gisev, Bell, and Chen, 2013). Agreement between two raters was also tested. follows.

The formula of the percent agreement is as

$$
\text { Percent agreement }=\frac{\text { Number of concordant responses }}{\text { Total number of responses }} \times 100 \%
$$

If the percent agreement is more than $70 \%$, the categorizations are valid. (Drisko and Maschi, 2016, p. 107) Similar to Drisko and Maschi (2016) Landis and Koch (1977) argue that in order to be substantial, percent agreement should be 61 to $80 \%$ and in order to be almost perfect, percent agreement should be 81 to $100 \%$. Landis and Koch (1977) still consider percent agreement of 41 to $60 \%$ to be moderate, but in this study, the researchers consider only percent agreement of $70 \%$ or more than $70 \%$ to be valid.

\section{RESULTS AND DISCUSSION}

\section{Results}

Research Results describe the number of positive, neutral, and negative action verbs, which referred to certain gender roles (female and male) and certain ethnicities (Austronesian, Melanesian, and Foreign ethnicities). The research results are divided into two parts, i.e. Action Verbs Representing Gender Roles and Action Verbs Representing Ethnicities. In both parts, the explanation is divided again into two parts, i.e. Sentences whose Subjects are Humans and Sentences whose Subjects are Animals, and in each of those parts, the explanation is divided again into three parts, i.e. Grade X, Grade XI, and Grade XII. The explanation of Sentences whose Subjects are $\mathrm{Hu}$ - mans and Sentences whose Subjects are Animals had to be separated since some animal subjects have unidentified gender roles and or ethnicities, which then made a new category, the unidentified. Different from Wulandari's (2019) thesis, this study does not discuss inanimate objects because no action verbs referred to inanimate objects. The findings in each grade of e-textbooks had to be separated since they had different writers and different total number of action verbs.

The percent agreement between the second researcher and IK regarding the categorization of the verbs was $77.27 \%$, and the percent agreement between the second researcher and AW was $90.91 \%$, which made the verb categorization valid because the percent agreement scores were more than 70\%. (Drisko \& Maschi, 2016, p. 107)

After cultural categorizations were done by the first researcher, the first researcher left the data for one month and re-categorized the data by using new blank tables. This technique, called multiple coding (Ena, 2013), was used to evaluate the consistency of categorizations. The researchers then employed two raters to categorize all the subjects having action verbs into the cultural categorizations. The percent agreement between J1 (the first researcher's first coding) and EHS, who was male Indonesian-Chinese, was $83.66 \%$; the percent agreement between $\mathrm{J} 1$ and $\mathrm{KN}$, who was male Alorese, is $49.08 \%$; the percent agreement between J2 (the first researcher's second coding) and EHS was 43.97\%; and the percent agreement between $\mathrm{J} 2$ and $\mathrm{KN}$ was $87.71 \%$.

Considering the bizarre of the cultural categorizations, the writers scrutinized the raw data and separate the negative action verbs from the other action verbs, and then calculated the percent agreement of the negative action verbs between J1, J2, EHS, and KN. The percent agreement between

$\mathrm{J} 1$ \& J2 was $77.77 \%$

$\mathrm{J} 1$ \& EHS was $88.89 \%$

J1 \& KN was $77.77 \%$

J2 \& EHS was $83.33 \%$

$\mathrm{J} 2$ \& $\mathrm{KN}$ was $100 \%$ and

EHS \& KN was $83.33 \%$.

\section{Action Verbs Representing Gender Roles}

The explanation of action verbs representing gender roles is divided into 1) action verbs representing gender roles in sentences whose subjects are humans, and 2) whose subjects are animals. Animal subjects are explained separately from human subjects because in some animal subjects, the gender could not be identified.

In the e-textbook for grade $X$, the ratio of 
Table 1. Action Verbs Representing Gender Roles in Sentences whose Subjects were Humans

\begin{tabular}{|c|c|c|c|c|c|c|c|c|c|c|}
\hline \multirow{2}{*}{$\begin{array}{l}\text { Language } \\
\text { Variables }\end{array}$} & \multicolumn{9}{|c|}{ Gender Roles } & \multirow{3}{*}{ 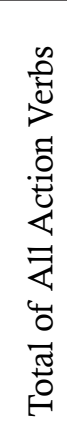 } \\
\hline & & Fem & & & & Iale & & & & \\
\hline \multirow{4}{*}{ 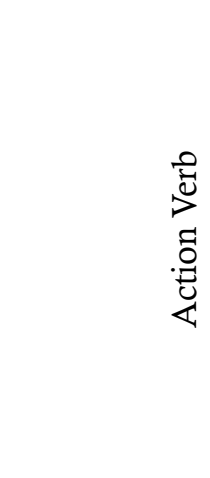 } & 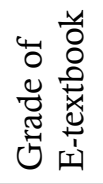 & + & $\mathrm{n}$ & - & 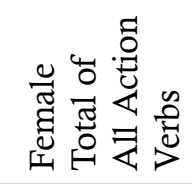 & + & $\mathrm{n}$ & - & 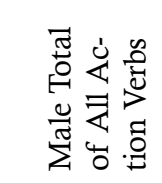 & \\
\hline & $\mathrm{X}$ & 118 & 108 & 16 & $\begin{array}{l}242 \\
49.59 \%\end{array}$ & 121 & 95 & 30 & $\begin{array}{l}246 \\
50.41 \%\end{array}$ & 488 \\
\hline & XI & 13 & 16 & 2 & $\begin{array}{l}31 \\
68.89 \%\end{array}$ & 6 & 7 & 1 & $\begin{array}{l}14 \\
31.11 \%\end{array}$ & 45 \\
\hline & XII & 33 & 22 & 2 & $\begin{array}{l}57 \\
45.97 \%\end{array}$ & 31 & 35 & 1 & $\begin{array}{l}67 \\
54.03 \%\end{array}$ & 124 \\
\hline
\end{tabular}

all action verbs whose subjects were female to all action verbs whose subjects were male was almost balanced. However, male subjects had almost twice more negative action verbs than the female. The female subjects had only 6.61 $\%$ of negative action verbs, while male subjects had $12.2 \%$ of negative action verbs. The percentage of negative action verbs belonging to male subjects might lead to gender bias. However, to claim this argument, more

In the e-textbook for grade XI, the number of all action verbs whose subjects were female dominated the e-textbook, while in the e-textbook for grade XII, the number of all action verbs whose subjects were male was only slightly higher than the number of all action verbs whose subjects were female. In both the e-textbook for grade XI and XII, the ratio of negative verbs whose subjects were female to negative verbs whose subjects were male was not a big deal.

In conclusion, generally there was no gender bias in action verbs representing gender roles in sentences whose subjects were humans. The high number of negative action verbs belonging to male subjects in the e-textbook for grade $\mathrm{X}$ is discussed in

\section{Discussion of the E-textbooks Studied.}

In the e-textbook for grade $X$, the ratio of all action verbs whose subjects were female to all action verbs whose subjects were male was perfectly balanced, while in the e-textbook for grade XI, the number of all action verbs whose subjects were male dominated the e-textbook. Contrary to those e-textbooks, in e-textbook for grade XII, the number of all action verbs whose subjects were unidentified gender roles dominated the e-textbook, followed by the number of all action verbs whose subjects were female. Considering the alternation of the domination, in conclusion, like in sentences whose subjects were humans, generally there was no gender bias in sentences whose subjects were animals.

\section{Action Verbs Representing Ethnicities}

The difference between the total of all action verbs representing gender roles and the total of all action verbs representing ethnicities was due to: 1) the gender roles of some subjects could be identified but their ethnicities could not be identified and vice versa 2) some subjects e.g. "we" referred to two gender roles, namely male and female, so "we" was categorized into one male subject and one female subject, but "we" referred to the same ethnicity, e.g. Austronesian ethnicity (Western Indonesia), so "we was categorized into one Austronesian ethnicity.

In the e-textbook for grade $\mathrm{X}$ and XII, clearly, Melanesian ethnicity was way too underrepresented. In the e-textbook for grade XI, compared to Foreign ethnicity, Melanesian ethnicity was equally represented, even though Austronesian ethnicity clearly dominated the e-textbook. Austronesian ethnicity dominated the e-textbooks for grade XI and XII, while the e-textbook for grade $\mathrm{X}$ was dominated by Foreign ethnicity.

In terms of negative action verbs, as shown in the table, only Foreign ethnicity in the e-textbook for grade $\mathrm{X}$ was represented by negative action verbs with the percentage of more than $10 \%$. 
Table 2. Action Verbs Representing Gender Roles in Sentences whose Subjects were Animals

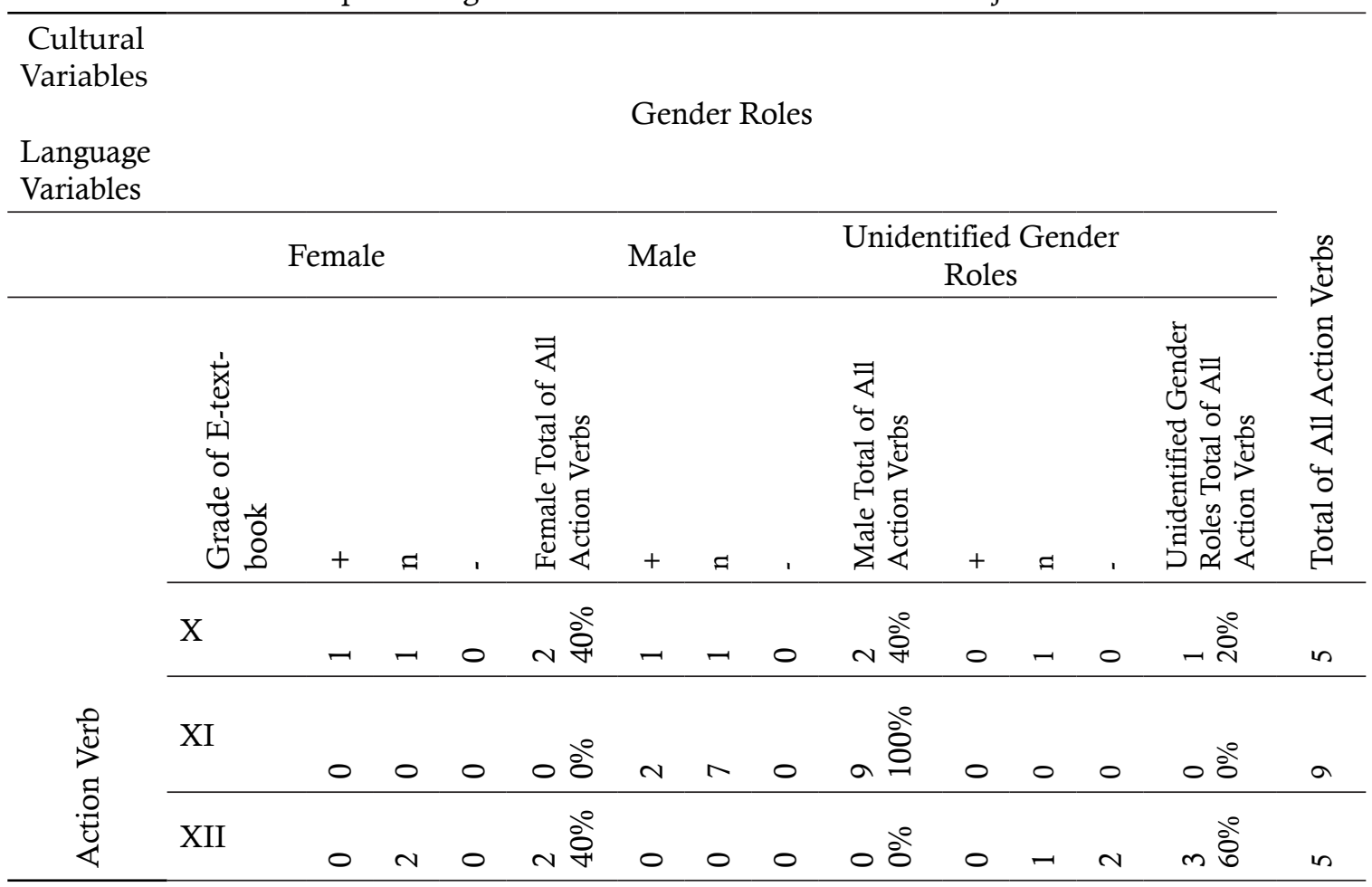

However, the percentage of negative action verbs belonging to the subjects whose ethnicity was Foreign in the e-textbook for grade XII was $0 \%$. The negative action verbs belonging to the subjects whose ethnicity was Foreign are discussed further in Discussion of the E-textbooks Studied.

In sum, unlike Austronesian and Foreign ethnicities, Melanesian ethnicity never dominated any e-textbooks studied. Mostly, Austronesian ethnicity dominated the e-textbooks studied. Generally, there was ethnicity bias in sentences whose subjects were humans.

There was no Melanesian animal subject in all the e-textbooks studied. Like in sentences whose subjects were humans, Melanesian ethnicity was way too underrepresented in sentences whose subjects were animals. Austronesian ethnicity dominated the e-textbook for grade $X$, while Foreign ethnicity dominated the e-textbook for grade XI. Even though unidentified ethnicities dominated the e-textbook for grade XII, most action verbs used were negative. If the negative action verbs were omitted, the e-textbook for grade XII was dominated by Foreign ethnicity. In sum, Foreign ethnicity had a tendency to dominate the e-textbooks studied, while Melanesian ethnicity had no chances to be represented in sentences whose subjects were animals. Generally, like in sentences whose subjects were humans, there was ethnicity bias in sentences whose subjects were animals.

\section{Discussion of Categories}

Discussion of categories; which is divided into two sub-sections, i.e. Positive and Neutral Action Verbs as Categories, and Negative Action Verbs as a Category; elaborates how and why certain action verbs were deemed to be positive, neutral, and negative; how valid the categories are; and how the categories reformed.

\section{Positive and Neutral Action Verbs as Categories}

Positive and neutral action verbs are discussed together in one section because there was some invalidity in positive and neutral action verbs as categories. The percent agreement between $\mathrm{J} 1$ and $\mathrm{KN}$ was $49.08 \%$ and the percent agreement between $\mathrm{J} 2$ and EHS is $43.97 \%$. Even though according to Landis and Koch (1977), those percentages are still deemed to be moderate, according to Drisko and Maschi (2016), only percentages of more than $70 \%$ are considered to be valid.

In chapter 3 , it is mentioned that an instrument including a categorization must be replicable, systematic, and transparent in order to build trustworthiness. Positive action verbs and neutral action verbs failed to be replicable due to the invalidity when tested with interraters.

What made $\mathrm{J} 1$ and $\mathrm{J} 2$ (multiple coding) have different classification results $(41.12 \%$ of percent agreement) was the first researcher's 
Table 3. Action Verbs Representing Ethnicities in Sentences whose Subjects were Humans

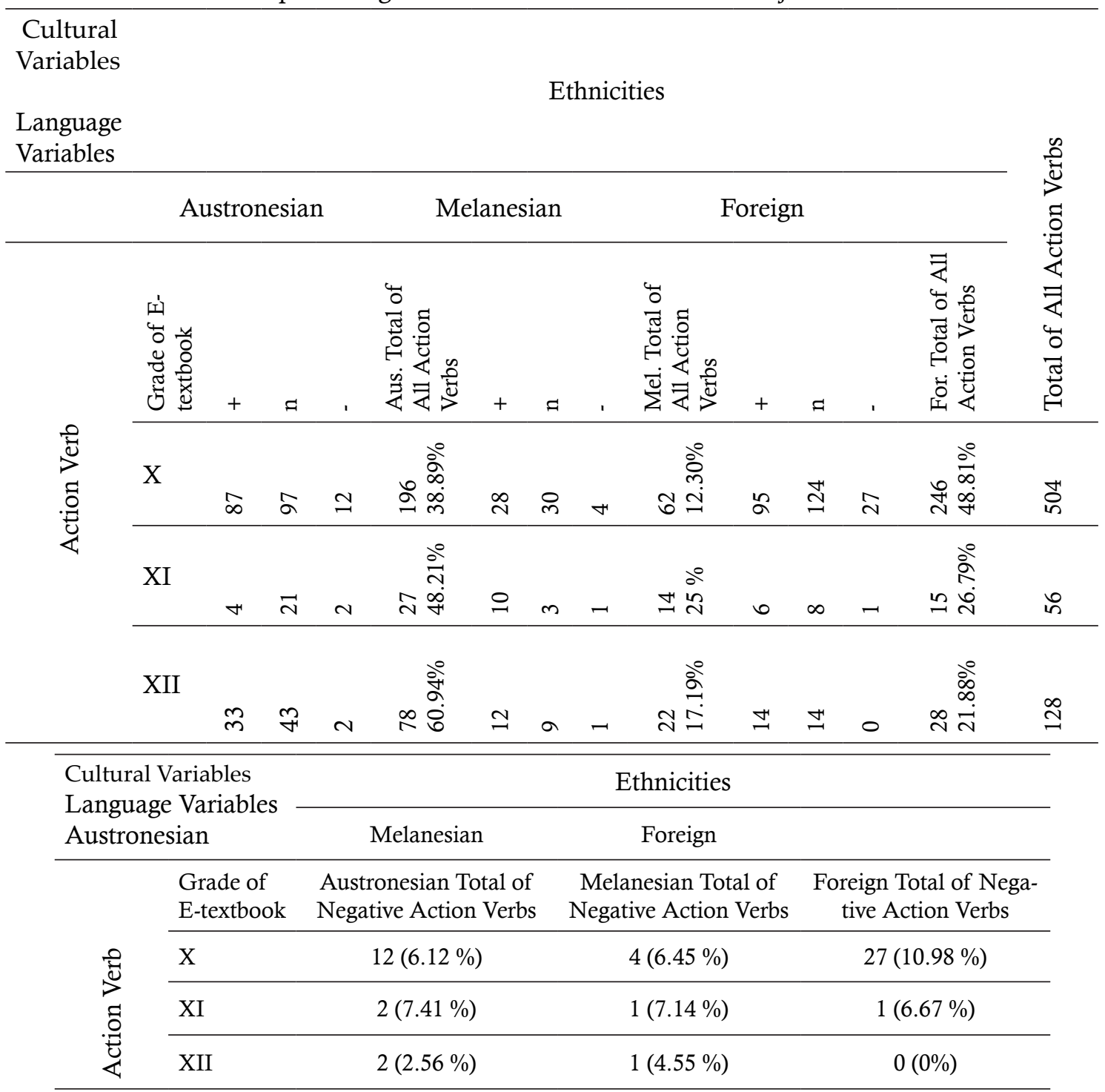

emotional state at the time the categorization processes were taken. The first coding, labeled J1, was when the first researcher was optimistic due to certain medication; while the second coding, taken a month afterward, was when the first researcher was not as optimistic as she had been due to the end of medication.

Even though some action verbs, e.g. get married, are verbs whose connotations depend heavily on cultural background, some verbs do not have a clear cultural border of positive and neutral connotations, so a person's emotional state plays an instrumental role in that of classification process. In places where marriage is deemed to be noble, get married tends to be labeled as a positive action verb. In places where marriage is merely a choice and there is no nobility attached to it, get married tends to be labeled as a neutral action verb. However, in sentences such as: (a) She told me that you sent her an email telling her that you would like to have more pen pals from the US; (b) Hannah told Alia that she was very happy; (c) Caroline introduces Alia to Hannah; the verbs tell and introduce, although considering the sentence contexts, still do not have a cut-clear cultural border of positive and neutral connotations.

In order to find further elaboration regarding this matter, the researchers gathered 11 random sentences from all e-textbooks and asked the interraters to categorize the action verbs in the sentences into positive, neutral and negative action verbs. Having a bright and optimistic personality, EHS easily classified told in She told me that you sent her an email telling her that you would like to have more pen pals from the US into a positive action verb, while $\mathrm{KN}$ classified the word told in the same sentence into a neutral action verb. $\mathrm{KN}$ said that the word told in the sentence 
Table 4. Action Verbs Representing Ethnicities in Sentences whose Subjects were Animals

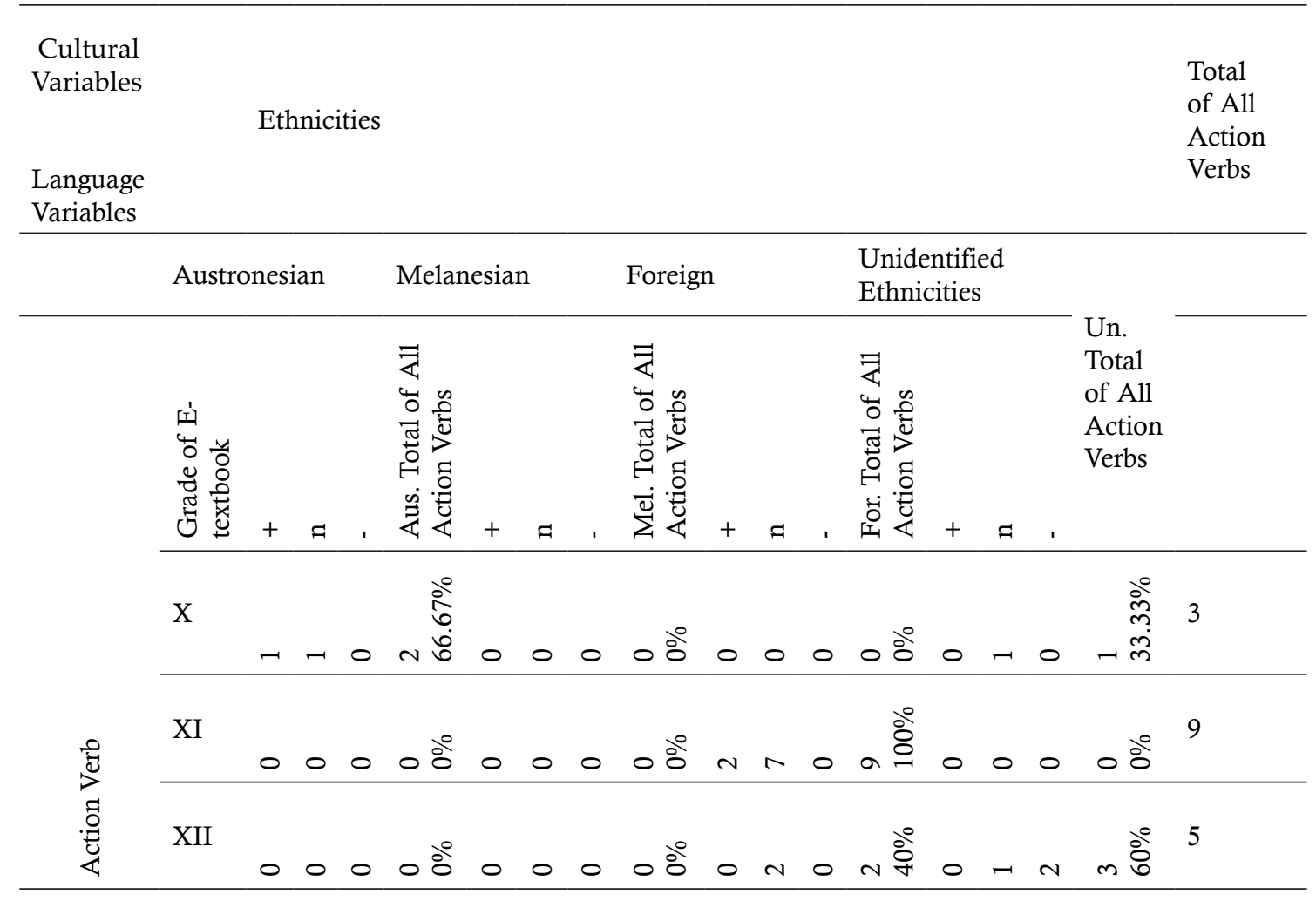

was "still neutral".

In this study, a person's emotional state and personality are not discussed, since this study only focuses on cultural aspects. Therefore, positive and neutral action verbs as categories have to be reconsidered. Considering the first phenomenon in preliminary study that positive action verbs and negative action verbs were not enough as the only categories used as the instrument, and also considering the phenomenon that in many cases, there was no boundary between positive and neutral action verbs, the writers suggest the proper category to be neutral to positive action verbs.

\section{Negative Action Verbs as a Category}

Negative action verbs as a category was a valid category because the percent agreements of the negative action verbs between the first researcher and all interraters were no less than $77.77 \%$. As mentioned in Positive and Neutral Action Verbs as Categories, after processing the data from all raters, the writers sent another 11 random sentences from all e-textbooks to the interraters in order to elaborate further the categorization processes done by the interraters. In the 11 random sentences, all raters agreed on all the negative action verbs, but often disagreed on positive and neutral action verbs. Therefore, negative action verbs remained to be a category and the writers suggest the future researches about action verbs utilizing Linguistic Category Model theory should use two categories, namely 1) neutral to positive action verbs 2) negative action verbs.

\section{Discussion of the E-textbooks Studied}

After discussing the categories, the connection between valid and trustworthy instruments, research results, and theories related to the reality has to be discussed. Due to the reconstruction of categorizations, i.e. 1) neutral to positive action verbs 2) negative action verbs, the writers focused only on the total number of action verbs and negative action verbs.

Regarding gender roles, nowadays, the number of men and women in Indonesia is almost balanced (Hakiki \& Ulfa, 2018, p. 7). In the research results, the same as Wulandari's (2019), in all the e-textbooks studied, the representation of men and women in the use of action verbs was relatively balanced. The high number of negative action verbs belonging to male subjects in the e-textbook for grade $\mathrm{X}$ was due to the colonizer characters in Chapter 9 The Battle of Surabaya and Chapter 11 Cut Nyak Dhien who were all males. The colonizers played an antagonistic role in those chapters, so that male subjects had many negative action verbs in the chapters. Outside those two chapters, generally, there was no gender bias in all the e-textbooks studied. The gender 
roles in all the e-textbooks studied were well represented in line with the reality.

In the e-textbooks studied, in sentences whose subjects were humans, Austronesian ethnicity had a tendency to dominate the e-textbooks; while in sentences whose subjects were animals, Foreign ethnicity had a tendency to dominate the e-textbooks. The negative action verbs belonging to the subjects whose ethnicity was Foreign in the e-textbook for grade $\mathrm{X}$ were also due to Chapter 9 and 11. Ironically, although represented negatively in the two chapters of the e-textbook for grade $\mathrm{X}$, Foreign ethnicity still dominated the e-textbook in sentences whose subjects were humans. In sentences whose subjects were animals, Foreign ethnicity had a chance to dominate the e-textbooks for grade XI and XII, while Melanesian animals had no chances to be represented at all. The same as Wulandari's (2019) research results, the results of this study showed that Melanesian ethnicity was way too underrepresented.

The rank of ethnicity domination in all the e-textbooks studied was Austronesian, Foreign, and Melanesian ethnicities. Regarding ethnicities, nowadays, the highest population in Indonesia is Austronesian, followed by Melanesian and Foreign ethnicities (Sudoyo et al., 2017). Therefore, the ethnicities in all the e-textbooks studied were represented different from the reality.

\section{CONCLUSIONS}

The validity of the methodology was achieved due to the maintenance of transparency of the process of systematic interpretation and the replicability of all instruments was rechecked and there was no problem. The researcher's interpretation, the categorizations, and the interrater agreement were all replicable because all of them were learnable and doable by everyone.

Having valid research instruments, the five major research results could be presented. The first major result was there was no gender bias in action verbs representing gender roles in sentences whose subjects were humans (it represented the reality). The second major result was there was no gender bias in sentences whose subjects were animals. The third major result was in the e-textbook for grade XI, in sentences whose subjects were humans, Melanesian ethnicity was almost equally represented as Foreign ethnicity, but never dominated any e-textbooks unlike Austronesian and Foreign ethnicities, even though in reality, the population of Melanesian ethnicity was larger in number than the population of Foreign ethnicity. The fourth major result was there was no Melanesian animal at all in all the e-textbooks studied. The final major result was negative action verbs made the subjects blamable. Inclusive learning materials should not marginalize any social groups and should be relatable to the students in order to maintain students' engagement with that of materials (Ghosh \& Galczynski, 2014, p. 137). According to Aziz (2011, August 26) the function of e-textbooks is to provide cheap or even free school textbooks for all Indonesian students without exception. If the e-textbooks were meant to be textbooks for all Indonesian high school students, the representation of gender roles and ethnicities should match the rank of population in reality.

Although representing gender roles in line with the population in reality, the e-textbooks did not represent the ethnicities in line with the rank of population in reality. Thus, the e-textbooks studied are good to be used only when there is no Melanesian student in a class at all, which is not always doable because Indonesian citizens selfidentify themselves as parts of certain ethnicities. Teachers may not always know the ethnicity of every student they teach. For example, a Caucasian-looking student may identify him or herself as a Melanesian person. Therefore, it is best to also use other learning materials (the inclusive ones) besides using the English e-textbooks of 2013 curriculum for high school in Indonesia. It is also wise for policy makers, textbook writers, and textbook publishers to pay more attention to creating inclusive learning materials.

\section{REFERENCES}

Amri, M., Bin-Tahir, S.Z., \& Ahmad, S. (2017). The Implementation of Islamic teaching in multiculturalism society: A case study at Pesantren Schools in Indonesia. Asian Social Science, 13 (6), 125-132.

Ari, D., Jacobs, L. C., \& Sorensen, C. (2010). Introduction to Research in Education: Eighth Edition. Canada: Wadsworth, Cengage Learning

Arifin, E. N., Ananta, A., Utami, D. R. W. W., Handayani, N. B. \& Pramono, A. (2015). Quantifying Indonesia's ethnic diversity. Asian Population Studies, 11(3), 233-256, DOI: 10.1080/17441730.2015.1090692

Ananta, A., Arifin, E. N., Hasbullah, M. S., Handayani, N. B., \& Pramono, A. (2015). Demography of Indonesia's Ethnicity. Singapore: Institute of Southeast Asian Studies. ISBN 9789814519885. OCLC 1011165696

Aziz, N. A. (2011, August 26). BSE Wujudkan Buku Teks Murah. Retrieved on December 12, 2019, from https://tekno.kompas.com/ $\mathrm{read} / 2011 / 08 / 26 / 20043086 /$ bse.wujudkan. 
buku.teks.murah

Baveye, Y., Dellandréa, E., Chamaret, C., and Chen, L. (2015) LIRIS-ACCEDE: A video database for affective content analysis. Ieee Transactions on Affective Computing, 6 (1), 43-55.

Bengtsson, M. (2016). How to plan and perform a qualitative study using content analysis. NursingPlus Open, 2, 8-14.

Candrawati, P., Nitiasih, P. K., \& Seken, I K. (2014). Sociocultural aspects representation: a content analysis on an EFL e-textbook for the twelfth graders in Indonesia. Jurnal Pendidikan Bahasa Inggris, 2(1).

Cavazos-Rehg, P. A., Krauss, M. J., Sowles, S., Connolly, S., Rosas, C., Bharadwaj, M., \& Bierut, L. J. (2016). A content analysis of depressionrelated tweets. Computers in Human Behavior, 54, 351-357.

Celce-Murcia, M. (2007). Rethinking the role of communicative aspects. In: E. A. Soler., \& M. P. S. Jordà (Eds.). Intercultural language use and language learning. Dordecht, The Netherlands: Springer. pp. 46-56

Cho, J. Y., \& Lee, E. (2014). Reducing confusion about grounded theory and qualitative content analysis: Similarities and differences. The Qualitative Report, 19(32), 1-20. Retrieved from https:// nsuworks.nova.edu/tqr/vol19/iss32/2

Drisko, J. W., \& Maschi, T. (2016). Content Analysis. New York: Oxford University Press

Elo, S., Kääriäinen, M., Kanste, O., Pölkki, T., Utriainen, K., \& Kyngäs, H. (2014). Qualitative Content Analysis: A Focus on Trustworthiness. SAGE Open.

Ena, Ouda. (2013). Visual Analysis of E-Textbooks for Senior High School in Indonesia. Dissertations. Paper 513. http://ecommons.luc.edu/ luc_diss $/ 513$

Ghosh, R., \& Galczynski, M. (2014). Redefining Multicultural Education, 3rd Edition: Inclusion and the Right to be Different. Toronto: Canadian Scholars' Press.

Gisev, N., Chen, T. F., \& Bell, J. S. (2013). Interrater agreement and interrater reliability: Key concepts, approaches, and applications. Research in Social and Administrative Pharmacy, 9, 330-338.

Hakiki, G., \& Ulfa, A. (2018). Women and Men in Indonesia 2017. Jakarta: BPS-Statistics Indonesia.

Holdford, D. (2008). Content analysis methods for conducting research in social and administrative pharmacy. Research in Social and Administrative Pharmacy, 4, 173-181.

Jackson, H. (2013). Grammar and Meaning: A Semantic Approach to English Grammar. New York: Routledge.

Jenkins, S., Yang, J. C-H., Ramalingam, S. S., Yu, K., Patel, S., Weston, S., Hodge, R., Cantarini, M., Jänne, P. A., Mitsudomi, T., \& Goss, G. D. (2017). Plasma ctDNA analysis for detection of the EGFR T790M mutation in patients with advanced non-small cell lung cancer. Journal of Thoracic Oncology, 12 (7), 1061-1070.
Kratzer A. (1996) Severing the external argument from its verb. In: Rooryck J., Zaring L. (Eds.) Phrase Structure and the Lexicon. Studies in Natural Language and Linguistic Theory, Vol. 33. Springer, Dordrecht.

Krippendorff, K. (2004). Content Analysis: An Introduction to Its Methodology. Thousand Oaks, CA.: Sage Publication Inc.

Landis, J. R., \& Koch G. G. (1977). The measurement of observer agreement for categorical data. Biometrics, 33, 159-174.

Lee, S. (2007). The relations between the studentteacher trust relationship and school success in the case of Korean middle schools. Educational Studies, 33(2), 209-216. DOI: 10.1080/03055690601068477

Mavridis, D. (2015). Ethnic Diversity and Social Capital in Indonesia, World Development, 67, 376395.

McNeish, J., Foster, M., Francescucci, A., \& West, B. (2012). The Surprising Foil to Online Education: Why Students Won't Give Up Paper Textbooks. Journal for Advancement of Marketing Education, 20(3), 58-69.

Moretti, F., Mazzi, M., Vliet, L. V., Bensing, J., Deledda, G., Rimondini, M., Zimmermann, C., \& Fletcher, I. (2011). A standardized approach to qualitative content analysis of focus group discussions from different countries. Patient Education and Counseling, 82, 420-428.

Neuendorf, K. A. (2002). The Content Analysis Guidebook. California: Sage Publications.

Olsen, M. B. (2014). A Semantic and Pragmatic Model of Lexical and Grammatical Aspect. New York: Routledge.

Parker, L., \& Hoon, C. Y.(2013). Secularity, Religion and the Possibilities for Religious Citizenship. Asian Journal of Social Science, 41(2), 150174.

Rubini, M., Moscatelli, S., \& Palmonari, A. (2007). Increasing Group Entitativity: Linguistic Intergroup Discrimination in the Minimal Group Paradigm. Group Processes \& Intergroup Relations, 10(2), 280-296.

Semin,G.R. (2008). Language Puzzles: A Prospective Retrospective on the Linguistic Category Model. Journal of Language and Social Psychology, 27 (2), 197-209.

Shrout, P. E., \& Fleiss, J. L. (1979). Intraclass Correlations : Uses in Assessing Rater Reliability. Psychological Bulletin, 86 (2), 420-428.

Sudoyo, T. S. H., Lauder, M. RMT., Lauder, A., Probonegoro, N. K., Putrohari, R. D., Usmany, D. P., Yapsenang, Y. P. N., Poelinggomang, E. L., \& Neonbasu, G. (2017). The Melanesian Diaspora in Indonesia: From Prehistory to the Present. Jakarta: Direktorat Sejarah, Direktorat Jenderal Kebudayaan, Kementerian Pendidikan dan Kebudayaan

Tilaar, H. A. R. (2009). Multikulturalisme: Tantangan Tantangan Global Masa Depan Dalam Transformasi Pendidikan Nasional. Jakarta: Grasindo 
Language Circle: Journal of Language and Literature 14(2) April 2020

Tixier, A. J.-P., Hallowell, M. R., Rajagopalan, B., \& Bowman, D. (2016). Automation in Construction, 62, 45-56.

Wulandari, A. (2019). Cultural diversity in the use of subjects in Indonesian senior high school e-textbooks: A content analysis. Thesis. Universitas Sanata Dharma, Daerah Istimewa Yogyakarta. (Unpublished) 